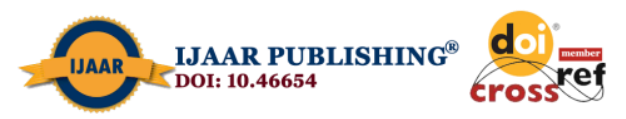

International Journal of Advanced Academic Research (Social and Management Sciences) | ISSN: 2488-9849

Journal DOI: 10.46654/ij.24889849

Vol. 6, Issue 7 (July, 2020) |www.ijaar.org

Article DOI: 10.46654/ij.24889849.s6723

\title{
EFFECT OF INTERNAL AUDIT FUNCTION ON FINANCIAL PERFORMANCE OF COMMERCIAL BANKS IN NIGERIA
}

\author{
Ezejiofor, Raymond Asika \\ Department of Accountancy \\ Nnamdi Azikiwe University, Awka \\ E-mail: thaddray4life@yahoo.com \\ Okolocha, Chizoba Bonaventure \\ Department of Entrepreneurship Studies \\ Nnamdi Azikiwe University, Awka \\ E-mail: cb.okolocha@unizik.edu.ng
}

\begin{abstract}
This study examines the effect of internal audit function on financial performance of commercial banks in Nigeria. The specific objectives of the study are to: determine the extent internal audit control significantly improve the financial performance of commercial banks in Nigeria and ascertain the level of internal audit procedures in curbing fraud to facilitate financial performance of commercial banks in Nigeria. This study adopted survey research design. The population of the study consists of seven (7) branches each from five (5) selected commercial banks in Enugu metropolis, Enugu State of Nigeria, which comprises of managers, internal control officers, fund transfer officer, and cash officers. Data collected for the study were analyzed by the researchers using frequency counts, mean score and standard deviation. The two hypotheses were tested using simple regression statistical tool with aid of SPSS version 20.0 at $5 \%$ level of significance. The analysis revealed that internal audit control and procedures have positive effect on financial performance of commercial banks in Nigeria and this effect is statistically significant at 5\% level of significance. The researchers recommended that the internal audit function in commercial banks in Nigeria internal audit department should ensure that financial fraud in their various establishments is being controlled and reduced to zero level.
\end{abstract}

Keywords: Internal Audit Function, Financial Performance and Commercial Banks. 


\section{INTRODUCTION}

Auditing today encompasses a wide range of activities, which have different set of objectives. Traditionally, it has been a control mechanism to provide assurance that the government officials or its ministries (internal audit) and the established legislature (external audit), that public funds are received and used in accordance with the required appropriate and established relevant laws and regulations (compliance audit) and that the government financial performance reports are true and fair and they are prepared from the underlying financial records and represents its financial position (financial audit). According to (Diamond, 2002), the audit function has involved in many countries to take a more comprehensive view of the economic and social implication of government operations often termed as "value for money" or "performance audit" (Ziniyel, Otoo \& Andzie, 2018).

Internal controls refer to the measures instituted by an organization so as to ensure attainment of the entity's objectives, goals and missions (Brennan \& Soloman, 2008). They are systems of policies and procedures that protect the assets of an organization, create reliable financial reporting, promote compliance with laws and regulations and achieve effective and efficient operations. By detecting weaknesses in management operations, Internal Auditing provides a basis for correcting deficiencies that have eluded the first line of defense before these deficiencies become uncontrollable or are exposed in the external auditor's report. These systems are not only related to accounting and reporting but also relate to the organizations communication processes, internally and externally, and include procedures for preparing appropriate and timely financial reporting to board members and officers, conducting the annual audit of the organization's financial statements, maintaining inventory records of real and other properties and their whereabouts. Tunji (2013) argues that internal controls encompass a set of rules, policies, and procedures an organization executes to provide reasonable assurance that its financial reports are reliable, operations are effective and efficient, and activities comply with applicable laws and regulations. The Committee of Sponsoring Organizations of the Treadway Commission (COSO, 2013) framework looks at internal control as a process, affected by an entity's board of directors, management and other personnel, designed to provide "reasonable assurance" regarding the achievement of objectives in the effectiveness and efficiency of operations, reliability of financial reporting, compliance with applicable laws and regulations.

Ziniyel, Otoo and Andzie (2018) documented that internal audit practice/activity is bedrock for effective public institutions financial management and it is imperative to ensure effective and efficient operations and the appropriate application of controls. The Internal audit practice is value added if it achieves its objectives by improving the organization regarding to governance, risk management and internal controls. The work of internal auditor is not complete until irregularities are rectified and remain rectified (Sawyer, 1995). It assesses compliance with underlying financial regulations, directives and measures, appraises the efficiency of adopted internal controls; evaluates the value and usefulness with which resources are utilized; evaluates the dependency and credibility of records maintenance and reporting; examines abnormalities; guarantees that resources are brought together and reported and authenticates inventory records and their identity with physical inventory (INTOSAL, 2001). 
Journal DOI: 10.46654/ij.24889849

Data from World Bank (2014) revealed that there was decline in service in all sectors of the economy including tourism. Poor financial performance of quoted companies adversely affects the economic growth of the Kenyan economy. There is however, continued poor financial performance, where budgets are not followed, rules and regulations on the use of finances are not adhered to and there are massive unaccounted funds. This has led to the risk of financial inadequacy, employee dissatisfaction and poor financial performance (Mikes \& Kaplan, 2014).

Nigerian banks have several internal control systems, but there is evidence that the financial management in Nigerian banks is not up to the expected standards locally and internationally, and this may create loop hole for financial impropriety or unfair view of the financial reporting as well resulted to rapid increase in merger and acquisition of banks in recent time in Nigeria

Studies on internal audit function mainly carried out in different part of the world with limited study in Nigeria such like; Ziniyel, Otoo and Andzie (2018) who concluded that there are effective internal audit practices necessary for influencing financial performance in Ghana. Bunu and Omwenga (2017) in their study concluded that Lamu County has an effective internal audit function that plays the role of monitoring and evaluating organization activities; It has an effective and efficient internal audit function which is able to detect fraud, but it is not able to prevent and control it .Abeer (2015) found that there is the effect of the function internal Audit to improve financial performance of the Jordanian commercial banks. In Nigeria, Ejoh and Ejom (2014) conducted a study in Cross River State College of Education, Akamkpa. The study found that the internal audit department of the College is not sufficiently staffed, does not perform their duties with greater degree of autonomy and independence from management. Also, study further revealed that internal audit function has no significant effect on the financial performance of Cross River State College of Education. This present study therefore examines the effect of internal audit function on financial performance of commercial banks in Enugu State of Nigeria. The specific objectives of the study are to:

1. Determine the extent internal audit control significantly improve the financial performance of commercial banks in Nigeria.

2. Ascertain the level of internal audit procedures in facilitating financial performance of commercial banks in Nigeria.

\section{REVIEW OF RELATED LITERATURE}

\section{Internal Audit Function}

Internal Audit has become an indispensable management tool for achieving effective control in both public and private organizations. Control mechanisms are those processes set up to monitor and to direct, promote or restrain the various activities of an enterprise for the purpose of seeing that enterprise objectives are met. Internal audit is an internal mechanism the members of the organization use in effective discharge of their responsibilities. It's also an independent appraisal function established within an organization to examine and evaluate the effectiveness, efficiency and economy of managements control system (Subramaniam, 2006). The aim is to provide management with re-assurance that their internal control systems are adequate for the need of the 
organization and are operating satisfactorily (Reid \& Ashelby, 2002). It is a component of the internal control system set-up by management of an enterprise to examine, evaluate and report operations of accounting and other controls. The quality and effectiveness of internal audit procedures in practice are necessary since internal auditors cover a wide variety of assignments, not all of which will relate to accounting areas in which the external auditor is interested.

Emasu (2007) reported that the effectiveness of internal audit function partly depends on; legal and regulatory framework, placement of the function and its independence, existence of auditlcommittees, resources allocated to the function and professionalism of internal audit staff" . It is however a bitter reality that internal audit departments are rarely adequately facilitated. Regarding the size and facilitation of the internal audit function, Gerrit and Mohammad (2010) found evidence in support of the monitoring role of the internal audit function. They specifically found evidence that management ownership is positively related to the relative size of the Internal Audit Function, which is inconsistent with traditional agency theory arguments that predict a negative relationship, but more in line with recent studies on earnings management.

Internal audits controls are planned to ensure that appropriate controls over systems and software are in place to ensure that internal controls and internal checks are functioning as designed (Haylas \& Ashton, 1982). Controls audits can have characteristics found into them to guarantee that falsified transactions are frowned upon or made cumbersome, if not impractical to perform. Controls audits present assurance that controls are functioning but they do not essentially identify fraud or corruption. Internal controls audit goals relay to organization plans, methods and procedures used to achieve the corporate mission, objectives and goals. Internal control also known as management controls includes planning, organizing, directing and controlling programme operations and the systems put in place to measure, report and monitor programme performance (Esmaijee, 1993).

\section{Empirical Review}

Ziniyel, Otoo and Andzie (2018) assessed the effectiveness of internal audit practice on financial management. A descriptive cross-sectional research design was used to analyze the research problem. Questionnaire and interview guide were used as the sources of data collection from audit staff, account staff and heads of institution across different campuses in one of the universities in Ghana. Data were analyzed with descriptive statistics binary logistics regression framework. The study revealed that the financial performance of internal auditors regarding the mandated guidance in the university is very great as indicated by $58.8 \%$ of the respondents. The study concluded that there are effective internal audit practices necessary for influencing financial performance. Bunu and Omwenga (2017) determined the effect of internal control systems on financial performance of Lamu County. The study collected both primary and secondary data. The researcher used structured questionnaires to collect primary data. Data was analyzed using descriptive statistical methods, frequencies and percentage with the aid of Microsoft Excel. The study concludes that Lamu County has an effective internal audit function that plays the role of monitoring and evaluating organization activities; it has an effective and 
efficient internal audit function which is able to detect fraud, but it is not able to prevent and control it. Mohammed, Shamsher, Taufiq and Zulkarnain (2011) examined the impact of the quality of the internal audit function (IAF), an integral part of corporate governance structure, on the financial reporting quality (FRQ) of all Saudi companies listed in the Saudi stock exchange (TADAWL) in 2009, excluding banks. Both secondary and primary information was collected through a matched survey and interview of internal and external auditors. The findings show weak association between IAF quality and FRQ. Abeer (2015) identify the impact of the internal audit function to improve the financial performance of the Jordanian commercial banks. The questionnaire was distributed to internal auditors working in the Internal Audit Department in the Jordanian commercial banks, and was analyzed by statistical package for social sciences (SPSS) program. The study found that the Jordanian banks are interested in the quality of internal audit and management of the internal audit activities and assess the risks of the internal audit process and that there is the effect of the function of internal Audit to improve financial performance. Ejoh and Ejom (2014) sought to establish the relationship between internal audit function and financial performance in Tertiary Institutions in Nigeria with particular reference to Cross River State College of Education, Akamkpa. Data was collected using questionnaires and the data were analyzed using simple percentages, tables, correlation coefficient and z-scores. The study revealed that all activities of the College are initiated by the top management. On the effectiveness of internal audit, the study found that the internal audit department of the College is not sufficiently staffed, does not perform their duties with greater degree of autonomy and independence from management. Also, study further revealed that internal audit function has no significant effect on the financial performance of Cross River State College of Education. Alkhasa (2013) determined the extent of the contribution of the internal audit function in the financial and administrative performance in local government bodies adjust to the Gaza Strip. The study relied on descriptive analytical method to describe and analyze the variables of the study and testing of hypotheses. The results revealed that the role of the internal audit function in the financial and administrative performance tuning, and that local authorities apply all the internal audit procedures to ensure the validity and accuracy of financial and administrative data. Abdali (2012) ascertained the impact of the application of the pillars of corporate governance in the quality of internal audit in industrial companies listed in Alardnellorac financial market. The results showed the presence of statistically significant effect of the application of the pillars of corporate governance in the quality of internal audit to industrial companies listed in Alardnellorac financial market. Slaves (2012) ascertained the role of the internal audit function in the environmental performance of industrial companies in Jordanian. Questionnaires were distributed to a sample of 60 employees of which 49 were valid for the analysis process. Results of the study showed that the Jordanian industrial companies based internal audit their environmental performance is average, which is reflected on its overall performance with the presence of some of the difficulties in the performance of the environmental audit process due to the lack of qualifications of internal auditors to assess. Jerboa (2005) identified areas of the contribution of the internal audit function in the financial performance tuning, and management at the Islamic University in Gaza. To achieve the objectives of the study, three questionnaires were distributed to the financial management personnel and internal auditors of university design. Results of the study showed that the areas which contributes to the internal auditor are: to identify the university needs of financial services, and administrative and advisory related to the field of control, as well as contribute to the detection of the strengths and weaknesses of the work 
required, and completed, revealing deviations, disability and deficiencies in internal control systems at the university also plays an important role in the two phases of research, diagnosis, and consideration of alternatives, and to contribute to solving problems, and the analysis and design of systems and procedures.

Studies on internal audit function mainly carried out in different parts of the world with limited study in Nigeria such like; Ghana, Lamu County, Jordanian etc, and found that there are effective internal audit practices necessary for influencing financial performance. In Nigeria, Ejoh and Ejom (2014) conducted a study in Cross River State College of Education, Akamkpa. The study found that the internal audit department of the College is not sufficiently staffed, does not perform their duties with greater degree of autonomy and independence from management. Also, study further revealed that internal audit function has no significant effect on the financial performance of Cross River State College of Education.

\section{METHODOLOGY}

\section{Research Design}

This study adopted survey research design. This design involves the use of sample to obtain the opinion of number of respondents. It is a research design that studies the information gathered from a fraction or percentage of the population.

\section{Population and sample size of the Study}

The population of the study consists of seven (7) branches each from five (5) selected deposit money banks in Enugu metropolis, Enugu State of Nigeria, namely; First bank plc, United Bank for Africa, Fidelity bank plc, Eco bank plc and Union bank plc. The element of the population comprises of managers, internal control officers, fund transfer officer, and cash officers. The total population is 140 . The researchers selected this percentage of the population for easy accessibility, considering the nature of the study which involved people's opinion through questionnaires administered to the targeted population for the study.

\section{Method of data collection}

There is a cover letter to the questionnaire addressed to the respondents, where they were assured that all information provided will be treated with utmost confidentiality and used for the purpose of the research work.

The questionnaire were close-ended questions on the research study, structured on a scale of Strongly Agree (SA), Agree (A), Undecided(UN), Disagree (D) and Strongly Disagree (SD); to give the respondents choice of ticking most perceived option. The researchers visited the banks with two assistants to administer the questionnaire to the respondents. The copies of the 
Journal DOI: 10.46654/ij.24889849

questionnaire distributed to the respondents were retrieved within two weeks after administration of the questionnaires.

\section{Method of Data Analysis}

Data collected for the study were analyzed by the researchers using frequency counts, mean score and standard deviation. The two hypotheses were tested using simple regression statistical tool with aid of SPSS version 20.0 at $5 \%$ level of significance.

\section{Decision Rule:}

The decision for the hypotheses is to accept the alternative hypotheses if the p-value of the test statistic is less or equal than the alpha and to reject the alternative hypotheses if the p-value of the test statistic is greater than alpha at $5 \%$ significance level.

\section{Model Specification}

The researcher estimated model in the following form:

FIPFM $_{\text {it }}=\mathrm{a} 0+\beta_{1} I A C_{\mathrm{it}}+\Sigma_{\mathrm{it}}$

FIPFM $_{\text {it }}=\mathrm{a} 0+\beta_{2} I A P_{\text {it }}+\Sigma_{\text {it }}$

Where:

The dependent variable: Financial performance (FINPFM) and

The independent variables:

$I A C=$ internal audit control

$I A P=$ internal audit procedure

$\mathrm{a} 0=$ slope of the model

$\beta I, \beta 2,=$ coefficient of parameters.

$i$ for the financial year ending at year $t$.

\section{DATA PRESENTATION AND ANALYSIS}

Out of 140 copies of questionnaires distributed, 104 were completed and returned. This represents $74 \%$. 
Journal DOI: 10.46654/ij.24889849

Table 1. Analysis of data collected on question one: To what extent has the internal audit control improves financial performance of commercial banks in Nigeria" ?

\begin{tabular}{|l|l|l|l|l|l|l|}
\hline & Questions & SA & A & Un & SD & D \\
\hline 1 & $\begin{array}{l}\text { Internal controls encompass a set of rules, policies, and procedures an } \\
\text { organization implements to provide reasonable assurance that its financial } \\
\text { reports are reliable }\end{array}$ & 33 & 55 & 5 & 0 & 11 \\
\hline 2 & $\begin{array}{l}\text { Internal audit control has designed an internal audit manual that guides audit } \\
\text { operations such as planning, monitoring, and evaluation. }\end{array}$ & 37 & 57 & 0 & 1 & 9 \\
\hline 3 & The internal audit control plays a vital role in detecting fraud in the banks. & 29 & 61 & 4 & 0 & 10 \\
\hline 4 & $\begin{array}{l}\text { The internal audit control assured the bank management with assurance that } \\
\text { there are no major internal control weaknesses are reported. }\end{array}$ & 31 & 58 & 3 & 0 & 12 \\
\hline 5 & $\begin{array}{l}\text { The internal audit control used internal audit results to assess the work of } \\
\text { the third parties on a regular basis. }\end{array}$ & 35 & 65 & 1 & 0 & 3 \\
\hline
\end{tabular}

Source: Field Survey, 2020

Table 2. Analysis of data collected on question two: What is the level of internal audit procedures in facilitate financial performance of commercial banks in Nigeria?

\begin{tabular}{|l|l|l|l|l|l|l|}
\hline & \multicolumn{1}{|c|}{ Questions } & SA & A & Un & SD & D \\
\hline 1 & $\begin{array}{l}\text { The internal audit procedures report to management on the extent of the } \\
\text { application of accounting principles and international. }\end{array}$ & 43 & 50 & 5 & 0 & 6 \\
\hline 2 & $\begin{array}{l}\text { Internal audit procedures planned stages accurately reveal the extent of } \\
\text { compliance of internal audit process. }\end{array}$ & 39 & 58 & 0 & 0 & 7 \\
\hline 3 & $\begin{array}{l}\text { The internal audit procedures provide timely completed of audit work and } \\
\text { ensure that internal audit findings are reported directly to top management }\end{array}$ & 34 & 60 & 4 & 1 & 5 \\
\hline 4 & $\begin{array}{l}\text { The internal audit procedures ensure that internal auditors in the bank } \\
\text { demonstrate professionalism and an objective approach. }\end{array}$ & 59 & 3 & 0 & 2 \\
\hline 5 & $\begin{array}{l}\text { Internal audit procedures monitor the performance of the internal auditor's } \\
\text { management to ensure compliance with internal audit standards. }\end{array}$ & 67 & 2 & 0 & 5 \\
\hline
\end{tabular}

Source: Field Survey, 2020 
Journal DOI: 10.46654/ij.24889849

Table 3. Analysis of data collected for question three: Proof of financial performance of commercial banks in Nigeria.

\begin{tabular}{|l|l|l|l|l|l|l|}
\hline & \multicolumn{1}{|c|}{ Questions } & SA & A & Un & SD & D \\
\hline 1 & $\begin{array}{l}\text { Financial performance gives evidence of accountability for the stewardship } \\
\text { of the resources as well contributing to evaluation of growth of the banks. }\end{array}$ & 39 & 60 & 1 & 0 & 4 \\
\hline 2 & $\begin{array}{l}\text { Financial performance makes available, vital information for good control } \\
\text { and prudent management of business activities. }\end{array}$ & 43 & 54 & 0 & 0 & 7 \\
\hline 3 & $\begin{array}{l}\text { Financial performance is based upon the possibility that banks had the } \\
\text { willful relationship of beneficial resources and those giving hope to get } \\
\text { value in return. }\end{array}$ & 34 & 66 & 4 & 0 & 0 \\
\hline 4 & $\begin{array}{l}\text { Financial performance provides completeness of all transactions undertaken } \\
\text { by an entity, the level of bank's assets, products and services }\end{array}$ & 41 & 55 & 0 & 0 & 8 \\
\hline 5 & $\begin{array}{l}\text { Financial performance reflects the outcomes of internal control } \\
\text { mechanisms, involving the receipt and disbursement in the banks. }\end{array}$ & 36 & 61 & 4 & 0 & 3 \\
\hline
\end{tabular}

Source: Field Survey, 2020

\section{Test of Hypotheses}

\section{Hypothesis one}

Ho: Internal audit control does not significantly improve financial performance of commercial banks in Nigeria.

Table 4: Model Summary

\begin{tabular}{|l|r|r|r|c|}
\hline Model & \multicolumn{1}{|c|}{$\mathrm{R}$} & \multicolumn{1}{|c|}{ R Square } & \multicolumn{1}{|c|}{$\begin{array}{c}\text { Adjusted R } \\
\text { Square }\end{array}$} & $\begin{array}{c}\text { Std. Error of the } \\
\text { Estimate }\end{array}$ \\
\hline 1 & $.992^{\mathrm{a}}$ & .984 & .979 & 19.42374 \\
\hline
\end{tabular}

a. Predictors: (Constant), IAC

Table 4 above shows that the Model revealed the value of $\mathrm{R}^{2}=0.984$ and Adjusted $\mathrm{R}^{2}$ value is .979. This suggests that the model explains about $98 \%$ of the systematic variations in the dependent variable. This means that the regression explains $98 \%$ of the variance in the data. The value of adjusted $\mathrm{R}^{2}$ of $98 \%$ also shows that $2 \%$ of the variation in the dependent variable is explained by other factors not captured in the study model.

Table 5: ANOVA ${ }^{\mathrm{a}}$

\begin{tabular}{|rl|r|r|r|r|r|}
\hline Model & & Sum of Squares & df & Mean Square & \multicolumn{1}{|c|}{ F } & \multicolumn{1}{c|}{ Sig. } \\
\hline & Regression & 70218.155 & 1 & 70218.155 & 186.116 & $.001^{\mathrm{b}}$ \\
& Residual & 1131.845 & 3 & 377.282 & & \\
& Total & 71350.000 & 4 & & & \\
\hline
\end{tabular}

a. Dependent Variable: FIPFM

b. Predictors: (Constant), IAC

In table 5 , it is revealed that the p-value is 0.001 which indicates that the hypothesis is statistically significant at level of significance $(5 \%)$; hence p-value of the test statistic is greater or equal to alpha. 
Journal DOI: 10.46654/ij.24889849

Vol. 6, Issue 7 (July, 2020) | www.ijaar.org

Table 6: Coefficients ${ }^{\mathrm{a}}$

\begin{tabular}{|c|c|c|c|c|c|c|}
\hline \multirow{2}{*}{\multicolumn{2}{|c|}{ Model }} & \multicolumn{2}{|c|}{ Unstandardized Coefficients } & \multirow{2}{*}{$\begin{array}{c}\text { Standardized } \\
\text { Coefficients } \\
\text { Beta }\end{array}$} & \multirow[t]{2}{*}{$\mathrm{t}$} & \multirow[t]{2}{*}{ Sig. } \\
\hline & & $\mathrm{B}$ & Std. Error & & & \\
\hline \multirow{2}{*}{1} & (Constant) & -5.835 & 11.844 & & -.493 & .656 \\
\hline & IAC & 1.056 & .077 & .992 & 13.642 & .001 \\
\hline
\end{tabular}

a. Dependent Variable: FIPFM

In table 6, the regressed coefficient correlation result shows that financial performance of commercial banks operating in Nigeria of the explanatory variable (Beta Column) shows 0.992 $(100 \%)$ means that internal audit control has up to 100 percent positive correlation with financial performance of commercial banks.

\section{Decision:}

Since p-value of the test statistic is less or equal to alpha, we therefore, reject null hypothesis and uphold alternative hypothesis which state that internal audit control has significantly improved financial performance of commercial banks in Nigeria.

\section{Hypothesis two}

Ho: The level of internal audit procedures does not facilitate financial performance of commercial banks in Nigeria.

Table 7: Model Summary

\begin{tabular}{|l|r|r|r|r|}
\hline Model & R & R Square & $\begin{array}{c}\text { Adjusted R } \\
\text { Square }\end{array}$ & $\begin{array}{c}\text { Std. Error of the } \\
\text { Estimate }\end{array}$ \\
\hline 1 & $1.000^{\mathrm{a}}$ & .999 & .999 & 4.38338 \\
\hline
\end{tabular}

a. Predictors: (Constant), IAP

Table 7 above shows that the Model revealed that the value of $\mathrm{R}^{2}=0.999$ and Adjusted $\mathrm{R}^{2}$ value is .999. This suggests that the model explains about $100 \%$ of the systematic variations in the dependent variable. This means that the regression explains $100 \%$ of the variance in the data. The value of adjusted $\mathrm{R}^{2}$ of $100 \%$ also shows that no percentage $(\%)$ of the variation in the dependent variable is explained by other factors in the study model.

Table 8: ANOVA ${ }^{\mathrm{a}}$

\begin{tabular}{|rl|r|r|r|r|r|}
\hline Model & & Sum of Squares & df & Mean Square & \multicolumn{1}{c|}{ F } & \multicolumn{1}{c|}{ Sig. } \\
\hline & Regression & 71292.358 & 1 & 71292.358 & 3710.430 & $.000^{\mathrm{b}}$ \\
1 & Residual & 57.642 & 3 & 19.214 & & \\
& Total & 71350.000 & 4 & & & \\
\hline
\end{tabular}

\footnotetext{
a. Dependent Variable: FIPFM

b. Predictors: (Constant), IAP
} 
In table 8 , it is revealed that the p-value is 0.000 which indicates that the hypothesis is statistically significant at level of significance $(5 \%)$; hence p-value of the test statistic is greater than alpha value.

Table 9: Coefficients ${ }^{\mathrm{a}}$

\begin{tabular}{|c|c|c|c|c|c|c|}
\hline \multirow{2}{*}{\multicolumn{2}{|c|}{ Model }} & \multicolumn{2}{|c|}{ Unstandardized Coefficients } & \multirow{2}{*}{$\begin{array}{c}\text { Standardized } \\
\text { Coefficients } \\
\text { Beta }\end{array}$} & \multirow[t]{2}{*}{$\mathrm{t}$} & \multirow[t]{2}{*}{ Sig. } \\
\hline & & $\mathrm{B}$ & Std. Error & & & \\
\hline \multirow{2}{*}{1} & (Constant) & -4.096 & 2.644 & & -1.549 & .219 \\
\hline & IAP & 1.039 & .017 & 1.000 & 60.913 & .000 \\
\hline
\end{tabular}

a. Dependent Variable: FIPFM

In table 9, the regressed coefficient correlation result shows that financial performance of commercial banks operating in Nigeria of the explanatory variable (Beta Column) shows 1.000 (100\%) means that internal audit procedures has up to 100 percent positive correlation with financial performance of commercial banks.

\section{Decision:}

Since p-value of the test statistic is less or equal to alpha, we therefore, reject null hypothesis and uphold alternative hypothesis which state that the level of internal audit procedures facilitates financial performance of commercial banks in Nigeria.

\section{CONCLUSION AND RECOMMENDATIONS}

This study assesses the extent internal audit function affects financial performance of commercial banks in Nigeria. The analysis revealed that internal audit control and procedures have positive effect on financial performance of commercial banks in Nigeria and this effect is statistically significant at $5 \%$ level of significance. The outcome of this study shows that commercial banks in Nigeria have an effective and efficient internal audit function to curb financial fraud. All these indicate that Nigerian banks have good internal control systems mechanism.

These results collaborate with the views of Ziniyel, Otoo and Andzie (2018) who concluded that there are effective internal audit practices necessary for influencing financial performance in Ghana, and Bunu and Omwenga (2017) who found that Lamu County has an effective internal audit function that plays the role of monitoring and evaluating organization activities; It has an effective and efficient internal audit function which is able to detect fraud, but it is not able to prevent and control it. As well, Abeer (2015) found that there is the effect of the internal Audit function to improve financial performance. Based on the above result, the researchers recommended the followings:

1. The internal audit function in commercial banks in Nigeria internal audit department should ensure that financial fraud in their various establishments is being controlled and reduced to zero level.

2. The internal auditors should comply with the audit procedures thereby demonstrate professionalism approach in executing their audit works. 


\section{REFERENCES}

Abeer, A. A., (2015). The impact of the internal audit functions to improve the financial performance of commercial banks in Jordan. Research Journal of Finance and Accounting 6(3). ISSN 2222-1697 (Paper) ISSN 2222-2847 (Online). www.iiste.org

Abdali, M.A. (2012). The impact of the application of corporate governance in the quality of internal audit in industrial companies listed on the Kuwait Stock Exchange, unpublished Master Thesis, University of the Middle East, Amman, Jordan.

Alkhasa, A. B. A., (2013). The contribution of the internal audit function in the financial and

administrative performance in local government bodies adjust to the Gaza Strip: An Empirical Study analytical, unpublished Master Thesis, the Islamic University, Gaza, Palestine.

Brennan, N. M., \& Soloman. J. (2008). Corporate Governance, Accountability and Mechanisms of Accountability: An overview. Accounting, Auditing \& Accountability Journal 21(7): 885-906.

Bunu, M. A. \& Omwenga, J. (2017). The effect of internal audit function on financial performance in Lamu County, Kenya. International Journal of Management and Commerce Innovations ISSN 2348-7585 (Online) 5(1) pp: (354-359), Available at: www.researchpublish.com.

COSO. (2013). Internal Control-Integrated Framework. Kpmg, Canada

Centre for Democracy and Development (CDD), Ghana (2000).

Diamond, J. (2002). The role of internal audit in Government financial management: An internal perspective. IMF working paper WP/02/94.

Ejoh, N. O. \& Ejom, P. E., (2014). The effect of internal audit function on the financial performance of tertiary institutions in Nigeria. International Journal of Economics, Commerce and Management Vol. II(10) http://ijecm.co.uk/ISSN 23480386

Emasu, S. (2007). Public financial management - Concepts and Practices, ACCA International Public Sector Bulletin, 7, 6-10

Hylas, R. E., \& Ashton, R. H. (1982). Audit detection of financial statement errors. Accounting Review, 751-765.

Jarbou, Y. M., (2005). The areas of the contribution of the internal audit function in the financial and administrative performance at the Islamic University tuning in Gaza, Palestine: A field study applied to financial management personnel and internal auditors, unpublished Master Thesis, the Islamic University, Gaza, Palestine.

Mikes, A., \& Kaplan, R. S. (2014). Towards a Contingency Theory of Enterprise Risk Management. AAA 
Journal DOI: 10.46654/ij.24889849 Vol. 6, Issue 7 (July, 2020) | www.ijaar.org

Mohammed A., Shamsher, M. R., Taufiq H. S. C. \& Zulkarnain , M. S. (2011). Impact of internal audit function (IAF) on financial reporting quality (FRQ): Evidence from Saudi Arabia. African Journal of Business Management Vol.5 (27), pp. 11189-11198.

Sawyer, L.B. (1995), “ An internal; audit philosophy”, The Internal Auditor, August, pp. 46-55.

Tunji, S. T. (2013). Effective internal controls system as antidote for distress in the banking industry in Nigeria. Journal of Economics and international Business Research, 1(5), $106-121$.

slaves, M. (2012). The role of the internal audit function in the environmental performance of industrial Jordanian companies evaluate, unpublished Master Thesis, Yarmouk University, Irbid, Jordan.

Ziniyel, D., Otoo, I. C. \& Andzie, T. A.(2018). Effect of internal audit practices on financial management. European Journal of Business, Economics and Accountancy. 6(3). ISSN 2056-6018.

World Bank (2014). The Global Competitiveness Report. World Economic Forum. Retrieved from http://www.worldbank.org/june-2013. 